\title{
Microfinancing, governance, and performance: a South Asian perspective
}

\author{
Asif Saeed
}

Institut de Recherche en Gestion (IRG), University Paris-EST Creteil, Creteil, France

Attiya Y. Javed

Pakistan Institute of Development Economics, Islamabad, Pakistan, and

Umara Noreen

Prince Sultan University, Riyadh, Saudi Arabia

\begin{abstract}
Purpose - This paper aims to investigate the relationship between microfinance institutions (MFIs) governance and performance.

Design/methodology/approach - Using a sample of 215 MFIs from six South Asian countries over the period from 2005 to 2009, the authors examine the effect of chief executive officer (CEO) duality, board size, female CEO, urban market coverage, bank regulation and lending type on financial and social performance of MFIs.

Findings - The findings provide evidence that, on the one hand, empowered CEO, large board size and individual lending improve the MFI financial performance and, on another hand, bank regulation and serving in the urban market have a significant association with MFIs' social performance. In an additional analysis, the authors also test this relationship before, during and after the financial crisis of 2007. During crisis period, MFIs' individual lending reduces the operational cost and bank regulation increases the average loan size in South Asian MFIs.

Originality/value - Those studies that are presented in the literature review conclude their result on the bases of global, European, East African and specific to some countries sample. There is no study presented in the whole literature on South Asian sample, in which all countries really face the problem of poverty.
\end{abstract}

Keywords Corporate governance, Financial performance, South Asia, Social performance

Paper type Research paper

\section{Introduction}

Microfinance provides financial services to very poor people for self-employed projects that produce revenue for them to support their families. Over the past 50 years, microfinance

JEL classification - G34, I32, L31, N85

(C) Asif Saeed, Attiya Y. Javed and Umara Noreen. Published in Journal of Economics, Finance and Administrative Science. Published by Emerald Publishing Limited. This article is published under the Creative Commons Attribution (CC BY 4.0) licence. Anyone may reproduce, distribute, translate and create derivative works of this article (for both commercial and noncommercial purposes), subject to full attribution to the original publication and authors. The full terms of this licence may be seen at http://creativecommons.org/licenses/by/4.0/legalcode

The authors are grateful to Zulfiqar Ali Shah and participants of 13th National Research Conference (Islamabad, Pakistan, 2011). The authors thank thesis jury members for their valuable comments.

Microfinancing, governance and performance

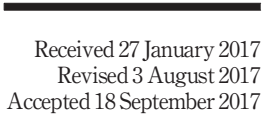

Accepted 18 September 2017 
JEFAS 23,46

248 institutions (MFIs) are playing an important role to reduce poverty in both underdeveloped and developing countries (Barry and Tacneng, 2014). Microfinance programs are recognized by the World Bank as an approach to address income inequality and alleviate the poverty. The implementation of microfinance schemes provides effective results in several South Asian countries (e.g. Bangladesh, Pakistan). World Bank declares "2005" [1] as a year of microfinance in the means to promote their poverty reduction goal. United Nations preset the agenda of "Transforming our world: the 2030 Agenda for Sustainable Development" in the year 2015. This agenda is a plan of actions for people, plant and prosperity. This sustainable development agenda is adopted by 193 countries around the world. This agenda contains 17 sustainable development goals,[2] and poverty eradication is one of the greatest challenges for member countries[3].

All financial institutions (e.g. banks, non-governmental organizations [NGOs], shareholder firms [4] and rural support programs) are very much interested in micro-financing activity but hesitate due to the weak financial position of credit clients. Generally, MFIs grant loans to a group of people for business purposes and charge them interest. Mostly, MFIs provide loans at a higher rate of interest that create hurdles for borrowers to repay the loans. Dr Muhammad Yunus, founder of Grameen Bank of Bangladesh, won Noble Peace Prize in 2006. The primary motive behind microfinance scheme of Grameen Bank was empowering poor people. Due to low interest rate and flexible terms of the loan agreement of this bank, the rate of recovery is more than 90 per cent (Khandker et al., 1998).

In this paper, we examine the role of governance practices to improve the performance (both financial and social) of South Asian MFIs. Ledgerwood (1998) broaden the core objective of MFIs that provide financial services not only to low-income persons but also to self-employed people. This study tries to find out that to what extent the MFIs' top management is successful to accomplish this goal. Provision of capital to the poor people acts as a supply of blood in a weak body and provides them a chance to improve their lives. Hartarska (2005) finds a significant relationship between governance and performance (financial and outreach) of the East European microfinance industry. In another study, Mersland and Strøm (2009) also investigate and support this relationship. In the light of above studies, we postulate that MFIs' governance has a significant association with performance, and we test this relationship with South Asian MFIs.

The main objective of this article is to find out the impact of good governance practices on the performance of South Asian MFIs. We study the different dimensions of MFIs' governance (such as chief executive officer [CEO] duality, board size, female CEO, urban market, bank regulation and individual lending) to investigate how they influence the financial and social performance of South Asia MFIs.

This study is based on the empirical analysis of 215 firm-year observations from 2005 to 2009; those are actively operating in this region. The members of the South Asian region are Afghanistan, Bangladesh, India, Nepal, Pakistan and Sri Lanka. In South Asian countries, India is the largest country in terms of area and population. Interestingly, half of the South Asian MFIs belong to this part of the region. According to benchmarking report (Mix Market, 2011), Afghanistan's microfinance industry observe maximum growth in 2007 and Pakistani MFIs demonstrate better outreach to their clients in 2008. This report highlights financial and social performance of the South Asian MFIs.

The purpose of this work is to enlighten those areas of corporate governance, which need more concentration to enhance the performance of the MFIs in South Asia. The governance data are collected from the website of MFIs and their annual reports, and financial data are obtained from Mix Market website (www.mixmarket.org). We applied pooled ordinary least squares regression to explore the impact of governance practices on MFIs performance. Our 
findings show that board size, female CEO, urban market and individual lending have a significant positive influence on MFIs financial performance. Nest, we find evidence that bank regulation and the urban market significantly reduce the social performance of MFIs. Regarding outreach, we find that firm attributes (e.g. firm size) play a key role to increase the average loan size and number of clients. MFIs facing poor performance issues can enhance their performance by following the governance structures of leading MFIs in their region. Our results are also consistent with random generalized least squares (GLS) technique. Furthermore, we also check this relationship before, during and after the crisis. Overall, we conclude that better governance practices of MFIs improve their financial and social performance in South Asian countries.

The rest of the paper proceeds as follows. Section 2 contains literature review and hypothesis. In Section 3, we discuss the data and sample in detail. Section 4 shows results of the empirical analysis. The additional results are given in Section 5. We conclude our study and provide some recommendations in Section 6.

\section{Literature review and hypothesis development}

\subsection{Microfinance institutions in South Asia}

Microfinance is a "program that extends small loans to very poor people for self-employment projects that generate income in allowing them to take care of themselves and their families" (Microcredit Summit in 1997) (Rahman, 1999). The primary purpose of this financing is to reduce poverty, which is a root cause of social crimes and unfair labor style. People are not able to improve their living standard due to non-provision of capital.

MFIs get fund at its primary stage from international donors or financial agencies (Germidis et al., 1991). Mostly, South Asian MFIs follow the same structure that is used by the Grameen Bank of Bangladesh (Hossain, 1988; Muhammad and Jolis, 1999). The Grameen Bank was established in early 70s; it functions the same as commercial banks and provides loans to a group of poor people. Grameen bank maintains its self-sufficiency at 20 per cent rate of interest. Microcredit Summit campaign report states that in 2002, 67.4 million families availed credit from microfinance all over the world. According to this report, out of 59.4 million Asian customers, 13 million were from Bangladesh. Ahmed (2009) find that MFIs have a great impact on the development of Bangladesh, where a large number of people live below poverty line, and he was serving as a governor of Bangladesh Bank at that time.

World Bank (2006) published a brief report on the MFI activities in South Asia. According to their analysis, Afghanistan and Nepal face many challenges due to bad political conditions. They also stress that the 17 per cent household are facilitated by South Asian MFIs. In 2005, the aggregate demand of microcredit was $\$ 15 \mathrm{bn}$, but only $\$ 2.3 \mathrm{bn}$ was provided to poor people. MFIs' coverage to its customer is better in India and Bangladesh and worst in Afghanistan and Sri Lanka. The lending amount of MFIs in Sri Lanka, Pakistan and Afghanistan is better than that in other countries of this region.

\subsection{Microfinance institutions' governance and performance}

Numerous studies examine the relationship between the MFIs governance and performance. The general definition of governance is that to what extent the organization achieves its goals with the help of its top management. Hartarska and Mersland (2012) state that large boards (up to nine members) are helpful to improve the performance of MFIs in terms of reaching many poor. They also show that CEO duality reduces the social performance. In a recent article of Tchuigoua (2015), he suggests that different board characteristics are the significant determinant of MFIs governance. In a conceptual paper, Estapé-Dubreuil and 
JEFAS 23,46
Torreguitart-Mirada (2015) support the above-mentioned findings and also suggest that the board has a significant association with the social performance of MFIs. Eisenberg et al. (1998) and Yermack (1996) state that large board size is related to a decrease in firm performance, calculated as return on assets (ROA). Bennedsen et al. (2008) verify the negative relationship in undersized firms and performance of SMEs. Hartarska (2005) also find a significant positive association between the MFIs' governance and performance.

Corporate governance plays an important role to enhance the financial and social performance of MFIs. Researchers state that MFIs with high level of board gender diversity provide females the glorious opportunity to reach at top management positions (Mori et al., 2013). Since, females as top executive prefer the female micro credit clients (Strøm et al., 2014).

MFIs' governance decisions (such as individual lending, urban market and regulatory structure) also have a significant influence on MFIs' performance. Cull and Morduch (2007) estimate the performance of MFIs through profitability and outreach by focusing on lending method. Using a global sample from more than 100 MFIs, they find that the financial performance improves with the help of individual lending. They have a low focus on governance issues and neglect the board characteristics. The lending methodology is divided into two types individual and group lending. Aghion and Morduch (2005) find that lending to the group may possibly increase the repayment of loan because it leads to optimistic matching. In another article, Cull and Morduch (2007) state that individual lenders repayment circle is large, whereas group lenders explain better outreach to the whole area. Hartarska and Nadolnyak (2007) mention that the regulatory authority has no straight effect on the performance of the MFIs, but these regulations influence the MFI outreach to the poorer customer. Mostly in India and Pakistan, MFIs are regulated by the government for better services and facilities to the poor.

A growing stream of literature highlights that we can measure the performance of MFIs with two different strands. On the strand of financial performance, Christen (2000) relates the performance with overall profitability by following terms: ROA, portfolio yield and operational cost. Jansson et al. (2004) state that nonprofit organizations are habitually projected to be weaker structure because they lack resources, which leads to slower performance in term of finance with compare to other MFIs. Hardy et al. (2003) find that all costs related to MFIs technology improvement, innovation into lending methodology or any other outreach improvement offset the MFI reimbursement. In another research, the performance of the firm is measured by ROA, operational self-sufficiency and many more different ways (Tucker and Kennedy-Tucker, 2004). The outreach of the MFIs is measured in two different ways: a number of clients served and the average loan size (Schreiner, 2002). Prior literature concludes that we can measure the financial (ROA, operational selfsufficiency, operating cost and portfolio yield) and social (average loan size and number of credit clients) performance of MFIs by different means.

MFIs' main object is to facilitate the poor people at maximum level. Same as other firms, MFIs' performance also receives effect from firm- and country-level determinants (such as size, age and gross domestic product). But MFIs have a big problem with credit risk assessment due to non-provision of collateral (Armendáriz and Morduch, 2010). On the MFIs' customer part, repayment and evaluation of credit risk are key concerning issues because credit clients have no property (Aghion and Morduch, 2005). Microfinance initiatives discover new sides to covenant with harms such as group lending, personality lending and the personal record of the client. At the country level, Human Development Index (HDI) is showing the lifestyle of the country people compared to other countries. Hartarska (2009) conclude that the all rating agencies had not the same impact on the 
investor or donor perception about the whole MFI industry. If the microfinance lending in a specific area or in a country increases the income and the food consumption of the poor community of that very area, it is a signal for household welfare improvement (Imai and Azam, 2012).

On the basis of above-mentioned literature, we conclude that the different governance dimensions have a strong influence on the performance of the MFIs. These studies produce their arguments on the bases of global, European, East African and specific to some countries sample. All countries of South Asia are extremely affected by governance and performance poverty. However, MFI literature has no evidence on the association between governance and performance of South Asian MFIs. In this study, we seek to fill this gap by proposing two hypotheses.

H1. Corporate governance has a significant impact on financial performance of South Asian MFIs.

H2. Corporate governance has a significant impact on the social performance of South Asian MFIs.

\section{Data and methodology}

To construct our sample, we start from Mix Market. According to Mix Market (2011) total, 175 organizations fully or partially provide the micro-financing facility in this region. Microfinance industry is at growing stage in South Asia. Christen et al. (2004) and Robinson (2001) discuss that the MFIs only facilitate the small part of world's poor. MFI includes banks, corporate, nonprofit organizations and shareholder's firms. Microfinancial banks are those institutions which established purely to provide the credit facility to poor people. These banks are also performing all functions like other commercial banks. MFIs are the perfect type of the organizations which made for a poor person for the credit facility. Nonprofit organizations, like NGOs, are also included in it. Rural support program is mainly focused on the rural area of the country to give the balance impact on the economy.

For support and to describe our analysis, we use statistics from third-party rating agency (www.themix.org). The data related to our governance variables are collected from websites of the organizations. The financial data are fetched from the Mix Market. Mix Market is a third-party rating company, which gathers data on MFIs globally from their local rating agencies. Mix Market also generates self-survey reports that are available on their Web.

Our sample technique is a convenient base because several microfinance organizations do not develop their sites and not effectively maintain their reports. In our sample, we cover one-fourth part of the MFIs in this region to show the original relationship. We collect data from 43 MFIs from 2005 to 2009 for the South Asian region. All the countries lay in this region have a different structure to raise the living standard of poor. We testify the performance of MFIs on two sides, one is financial and other is a social performance that is also called outreach.

\subsection{Econometric model}

Following the prior studies (Mersland and Strøm, 2009; Hartarska, 2005), we estimate the corporate governance variables. We regress the financial and social performance of the MFIs on the corporate governance measures along with control variables. According to our data, we formulate the two equations. Our regression models are: 
JEFAS

23,46

252

$$
\begin{aligned}
\text { Financial_Performance }_{i t} & =\alpha_{0}+\beta_{1} \text { ceo }_{i t}+\beta_{2} b s_{i t}+\beta_{3} \text { fceo }_{i t}+\beta_{4} u m_{i t}+\beta_{5} b r_{i t} \\
& +\beta_{6} i l_{i t}+\beta_{7} \text { size }_{i t}+\beta_{8} a g e_{i t}+\beta_{9} p r_{i t}+\beta_{10} h d i_{i t} \\
& +\beta_{11} D_{-} \text {Year }_{i t}+\beta_{12} D_{-} \text {Country }+\mu_{i t}
\end{aligned}
$$

$$
\begin{aligned}
\text { Social_Performance }_{i t} & =\alpha_{0}+\beta_{1} \text { ceo }_{i t}+\beta_{2} b_{i t}+\beta_{3} f c e o_{i t}+\beta_{4} u m_{i t}+\beta_{5} b r_{i t} \\
& +\beta_{6} i l_{i t}+\beta_{7} \text { size }_{i t}+\beta_{8} \text { age }_{i t}+\beta_{9} \text { prit }_{i t}+\beta_{10} h d i_{i t} \\
& +\beta_{11} D_{-} \text {Year }_{i t}+\beta_{12} D_{-} \text {Country }+\mu_{i t}
\end{aligned}
$$

The first model equation checks the impact of corporate governance on the financial performance of MFIs. For financial performance, we select return on asset, operational selfsufficiency, portfolio yield and operational cost. The second model equation checks the association between governance and social performance of the MFIs. Most of the MFIs are working as a nonprofit institution so that the social performance of the MFIs is also very important with financial performance. Appendix contains the definitions of all variables.

\section{Empirical results}

\subsection{Microfinance institutions in South Asia: a graphical view}

According to Mix Market data, the outreach of Bangladesh is better than other countries. They are providing more microfinancing facility to their peoples as shown in Figure 1 . This figure clearly shows that Bangladesh providing microlending to around 1.5 million people those are three times greater than India and more than the accumulation of the other five countries in South Asia.

Figure 2 presents the average amount of loan granted to an individual client. MFIs that operate in Afghanistan grant maximum $\$ 250$. The gradual increase in loan amount is from

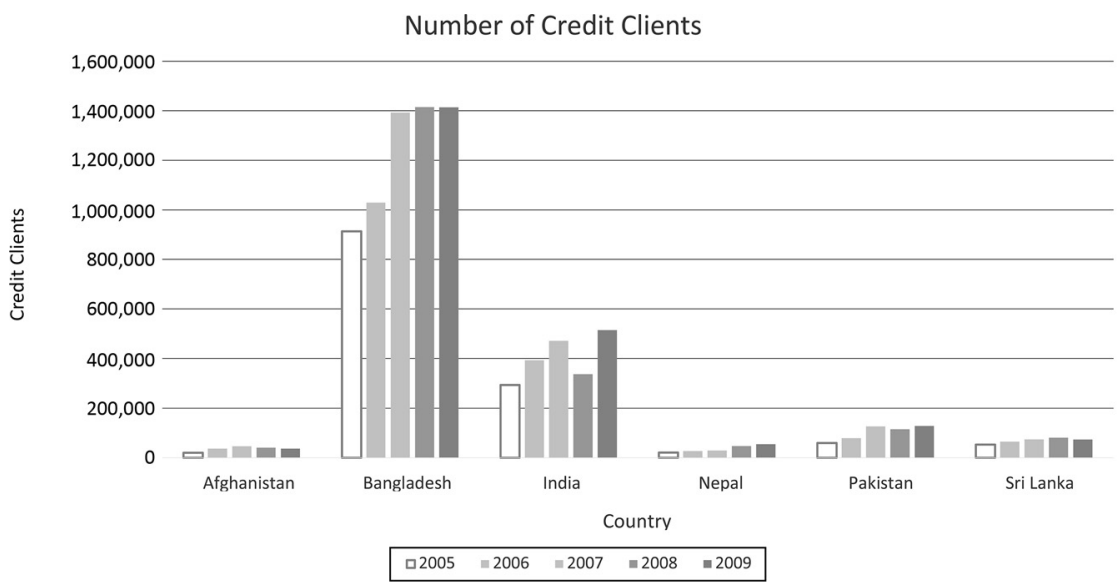

Figure 1.

MFIs year-wise total number of clients
Notes: This figure presents the bar chart of the total number of credit clients over the period of 2005 to 2009; this data is obtained from Mix Market and show the mean value of each country on yearly basis 


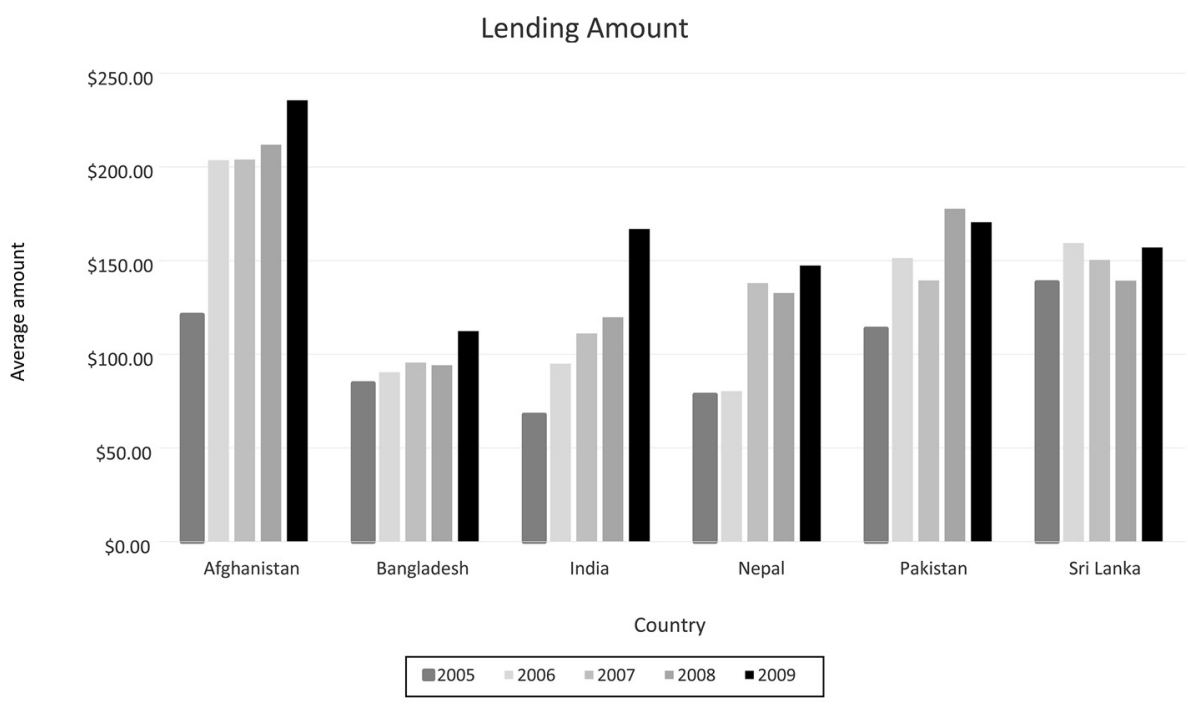

Notes: This figure presents the bar chart of the average amount of loan per client over the period of 2005 to 2009; this data is obtained from Mix Market and show the mean value of each country on yearly basis
Microfinancing, governance and performance

253

Figure 2.

MFIs year-wise total lending amount granted to a single client

2005, and this increase is may be due to American presence there, and the MFIs working under their supervision sanctioned more amounts compared to the past years. All other countries on average granted $\$ 150$ to each credit client for his business.

When MFIs provide the finance to the poor, then the lifestyle of those people should be improved. We measure the country life standard with help of HDI. The HDI ranking of south Asian countries is presented in Figure 3. According to United Nations Development Programme (UNDP), Sri Lankans are more developed compared to the other countries of this region. The people of Afghanistan are at the bottom, and nonprofit organizations should invest in this country to uplift the standard of their lives that are affected by the war.

\subsection{Descriptive statistics}

To test our hypothesis, we collect data from $43 \mathrm{MFIs}$ out of the 175 . We gather these data for five consecutive years from 2005 to 2009. To form symmetry in this data, we make our data annualized and the financial data are converted into dollar form. Mix Market has a data on more than 1,200 institutions from all over the world. Table I shows that the MFIs in this region have mostly served at the breakeven point and sometimes in loss because the ROA ratio shows -2 per cent mean. The operational self-sufficiency of these institutions is good, and 82 per cent relies on their own resources. The average loan amount granted to an individual client is $\$ 129$; this amount is only to purchase on average one goat. To sanction these loans to the poor persons, MFI incurred 20 per cent operational costs. The average of credit clients served by a single MFI is 0.36 million; this is a huge amount showing the current potential of MFI industry in this region.

Most microfinance organizations working in this region have a dual leadership structure. Average board size is nine members, which is more compared with the previous researches (Mori et al., 2013; Hartarska, 2005). In top-level management the board gender diversity is 
JEFAS

23,46

254

Figure 3.

HDI of South Asian countries

\section{Countries HDI Ranking}

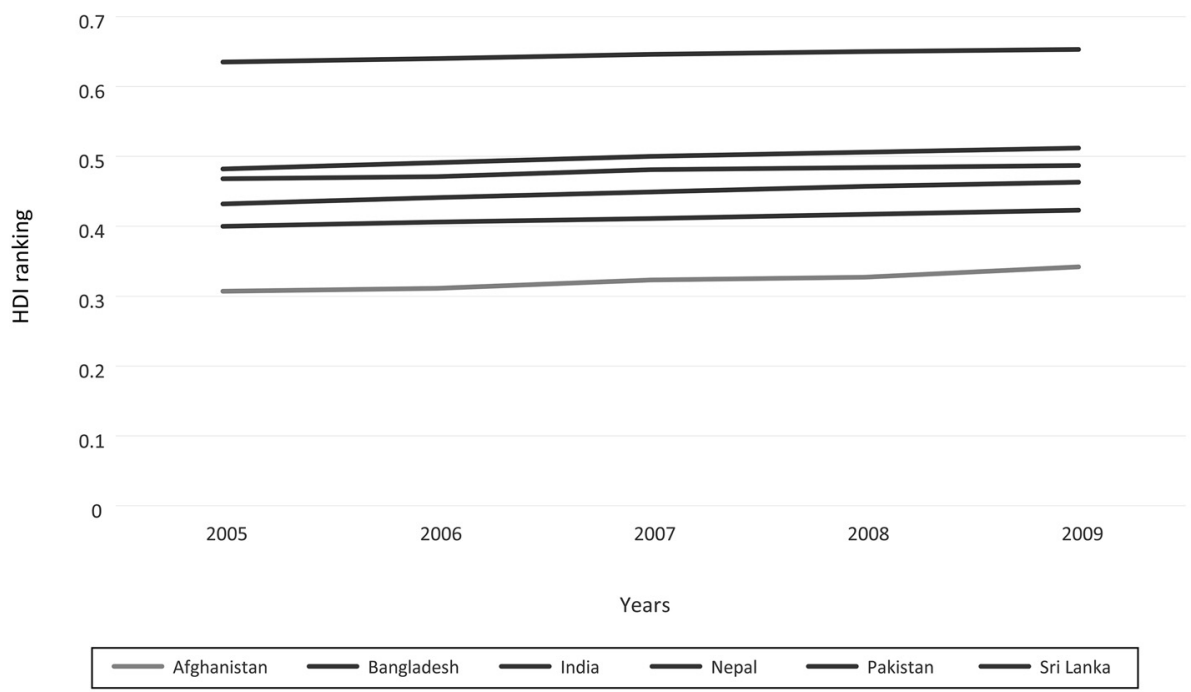

Notes: This figure presents the line chart of Human Development Index (HDI) over the period of 2005 to 2009; this data is obtained from UNDP reports and show HDI value for each country on yearly basis

not appreciated in this region. MFIs serving in this region also target the urban market because low-income people also live in urban areas. The mean age of the institutions working in this region shows that they have a moderate-level experience. If the financial system is governed by state, then it is more active, and approximately half of the MFIs follow the bank regulation.

The correlation matrix shows the relationship between the independent variables. Some of the variables are significant at 0.01 level and some are at the level of 0.05 . We apply Pearson correlation on all explanatory variables. Table II shows the correlation matrix between independent variables to check the multicollinearity concerns. Multicollinearity problem exists when the correlation among the variable is greater than 0.7 (Kennedy, 2008). The maximum correlation reported in Table II is not more than 0.34 . On the bases of these results, we can say that multicollinearity is not an issue in our data.

\subsection{Effect of Governance on the performance of microfinance institutions}

We begin by using the financial performance measures as the dependent variable. Then we estimate the same model with social performance measures. Favorable "F statistic" value in all the six models shows the fitness of our model and $R^{2}$ shows the overall variations in dependent variable explained by independent variables.

We first estimate our econometric model without control variables. In Table III, the first four models show the corporate governance impact on financial performance of MFIs without control variables. According to results, the female CEO improves the 


\begin{tabular}{|c|c|c|c|c|c|c|c|}
\hline Variables & $N$ & Mean & Std. dev & Min & Median & $\operatorname{Max}$ & ing, \\
\hline \multicolumn{7}{|l|}{ Dependent } & $e$ \\
\hline ROA & 215 & -0.021 & 0.178 & -1.404 & 0.000 & 0.652 & \\
\hline OSS & 215 & 0.825 & 0.535 & -0.192 & 0.964 & 3.357 & \\
\hline Operational_Cost & 215 & 0.200 & 0.279 & 0.000 & 0.121 & 2.194 & \\
\hline Portfolio_Yield & 215 & 0.217 & 0.159 & 0.000 & 0.218 & 1.155 & \\
\hline Average_Loan & 215 & 128.851 & 79.744 & 0.000 & 121.000 & 432.000 & 255 \\
\hline Credit_Client & 215 & 358,276 & $1,063,578$ & 0.000 & 47,265 & $6,397,635$ & \\
\hline \multicolumn{8}{|l|}{ Independent } \\
\hline CEO_Dulality & 215 & 0.698 & 0.460 & 0.000 & 1.000 & 1.000 & \\
\hline Board_Size & 215 & 9.558 & 4.869 & 3.000 & 8.000 & 21.000 & \\
\hline Female_CEO & 215 & 0.047 & 0.211 & 0.000 & 0.000 & 1.000 & \\
\hline Urban_Market & 215 & 0.419 & 0.494 & 0.000 & 0.000 & 1.000 & \\
\hline 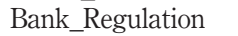 & 215 & 0.465 & 0.500 & 0.000 & 0.000 & 1.000 & \\
\hline IndividualLending & 215 & 0.419 & 0.494 & 0.000 & 0.000 & 1.000 & \\
\hline \multicolumn{8}{|l|}{ Control } \\
\hline Age & 215 & 11.851 & 10.748 & 0.000 & 8.000 & 51.000 & \\
\hline Size & 215 & 14.689 & 5.141 & 0.000 & 16.043 & 20.714 & \\
\hline Portfolio_Risk $<30$ & 215 & 0.071 & 0.243 & 0.000 & 0.011 & 3.041 & Table I. \\
\hline HDI & 215 & 0.477 & 0.078 & 0.307 & 0.484 & 0.653 & Descriptive statistics \\
\hline \multicolumn{8}{|c|}{$\begin{array}{lr}\text { Notes: This table provides the descriptive statistics of variables used in this study. Our sample consists of } & \begin{array}{r}\text { of dependent and } \\
\text { independent }\end{array} \\
215 \text { firm-year observations from } 43 \text { South Asian MFIs over the period from } 2005 \text { to } 2009 \text {. Appendix reports } & \text { variables } \\
\text { the definitions of regression variables. Own elaboration }\end{array}$} \\
\hline
\end{tabular}

operational self-sufficiency of a firm in this region. The dual CEO that attributes and serves in the urban market increase the MFIs' operational cost. Portfolio yield has a positive association with urban market. In next two models, we measure the association between governance and social performance. Regulated MFIs are not able to target the maximum number of credit clients.

\begin{tabular}{|c|c|c|c|c|c|c|c|c|c|c|c|}
\hline Variables & $\mathrm{N}$ & 1 & 2 & 3 & 4 & 5 & 6 & 7 & 8 & 9 & 10 \\
\hline 1.CEO_Duality & 215 & 1.00 & & & & & & & & & \\
\hline 2. Board_Size & 215 & $0.10^{*}$ & 1.00 & & & & & & & & \\
\hline 3. Female_CEO & 215 & $-0.34^{* * *}$ & $0.11 *$ & 1.00 & & & & & & & \\
\hline 4. Urban_Market & 215 & $-0.26^{* *}$ & $-0.23^{* *}$ & $0.26 * *$ & 1.00 & & & & & & \\
\hline 5. Bank_Regulation & 215 & 0.00 & $-0.17 *$ & 0.02 & $-0.13^{*}$ & 1.00 & & & & & \\
\hline 6. Individual_Lending & 215 & $0.25 * *$ & $-0.21^{* *}$ & $-0.19 *$ & 0.04 & 0.06 & 1.00 & & & & \\
\hline 7. Age & 215 & $0.16^{*}$ & $0.21 * *$ & 0.01 & $-0.12^{*}$ & 0.08 & $0.23^{* * *}$ & 1.00 & & & \\
\hline 8. Size & 215 & -0.03 & -0.09 & $0.14^{*}$ & 0.06 & -0.05 & -0.08 & -0.02 & 1.00 & & \\
\hline 9. Portfolio_Risk $<30$ & 215 & 0.00 & 0.07 & -0.05 & -0.08 & 0.04 & 0.02 & 0.01 & 0.04 & 1.00 & \\
\hline 10. HDI & 215 & 0.07 & -0.04 & -0.01 & -0.09 & $0.35^{* * *}$ & $0.11^{*}$ & 0.01 & 0.01 & $-0.11^{*}$ & 1.00 \\
\hline
\end{tabular}

Notes: This table reports Pearson correlation between independent variables used in our regression; our sample consists of 215 firm-year observations from 43 South Asian MFIs over the period from 2005 to 2009; Appendix reports the definitions of key regression variables; *statistically significant at $10 \%$; ***statistically significant at $5 \%$; ***statistically significant at $1 \%$

Source: Own elaboration

Table II.

Correlation matrix of all independent variables 
JEFAS

23,46

256
Table III.

Corporate

governance and performance without control variables

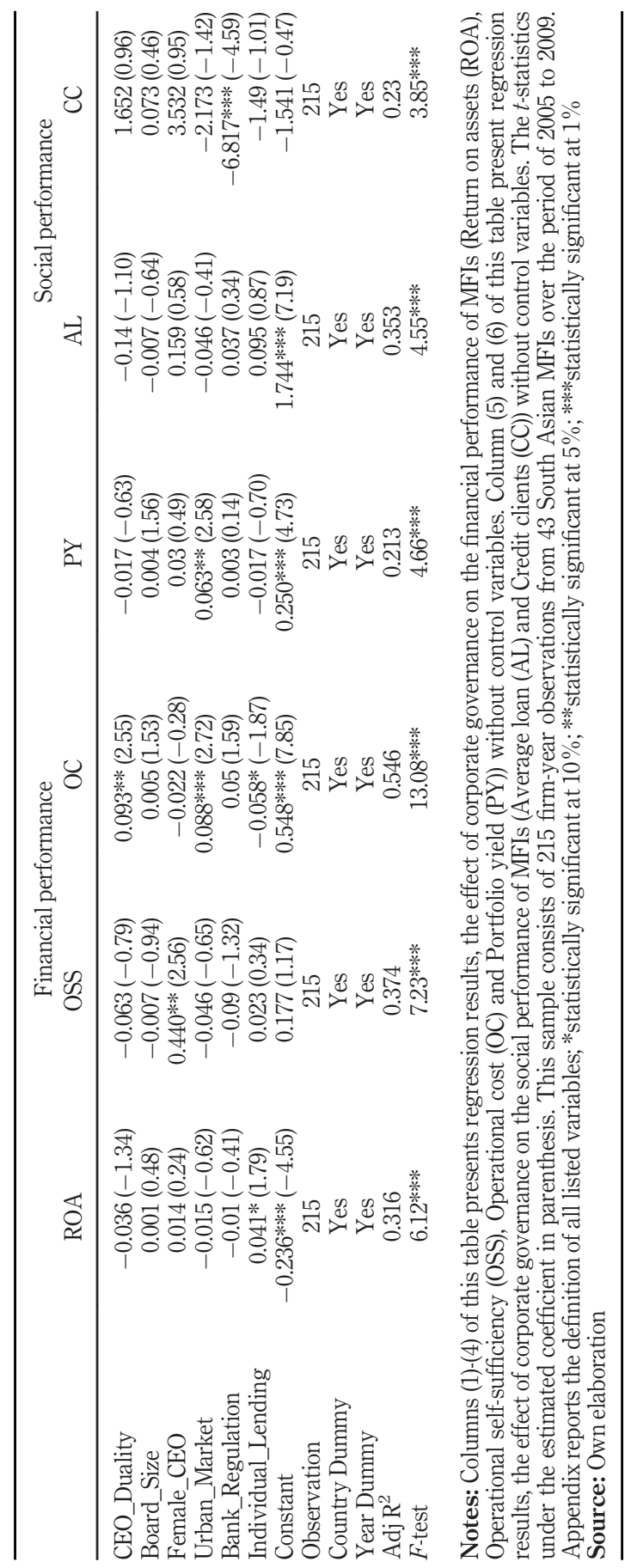


All the four measures of financial performance (ROA, operational self-sufficiency, operational cost and portfolio yield) and two measures of social performance (average loan and credit clients) are estimated in Table IV with control and dummy setting. The results are improved with control setting. The CEO holds both positions at the same time can increase the operational cost and reduces the MFIs profits. In South Asian MFIs, the duality is not in the favor of the institution. Maximum, the number of board member have a good impact on the portfolio yield. Female CEO is very helpful to increase the operational self-sufficiency of the MFIs. If MFIs are regulated by the bank, it will increase its operational cost. Individual lending is preferable than group lending because it increases the profitability (ROA) of the MFIs.

Corporate governance of MFIs has a little impact on social performance. In previous studies, the social performance of the MFIs is also named as an outreach of the MFIs (Mersland and Strøm, 2009). If MFIs are only operational in urban markets, it will reduce the total number of clients. Regulated MFIs are not able to target a maximum number of clients. In a social performance context, all these impacts are mainly generated by the size of MFI.

\section{Additional analysis}

In an additional analysis section, we run all the six equations with alternative regression framework. Following previous studies (Greene, 2003), we use GLS random effect on our data.

In Table V, we test our hypothesis with GLS method. The results show that the CEO duality in South Asian MFIs can increase the operational cost. Overall, results with GLS method are similar to our main findings in terms of all explanatory variables. The significant coefficient of average loan size depends on the microfinancing institution size. Countries with better HDI are favorable for MFIs to reduce their operational cost. If MFI portfolio at risk is greater than 30 days, it will increase the operational cost of the institution. MFIs' specific characteristics such as size and portfolio risk greater than 30 days have a strong impact on the financial performance. The overall $R^{2}$ square and Wald Chi-square statistics show the variable explanation and fitness of the model.

Our data consist of five years from 2005 to 2009, and this period also includes the financial crisis period of 2007. Wagner and Winkler (2013) stress that financial crisis of 2007 also affects the micro-financial institution of South Asia. They further elaborate that the financial crisis strongly impacts the microfinance bank rather than institutions.

In Tables VI and VII, we estimate the impact of corporate governance on firm performance before (2005-06), during (2007) and after (2008-2009) crisis. Before the financial crisis, the maximum number of board size was positively associated with portfolio yield and average loan size. This relationship does not exist during and after the crisis. After crisis, CEO duality has a negative impact on the firm performance in shape of lower returns and higher operating costs. During the crisis, only bank regulation increases the size of the average loan and individual landing reduces the operating cost in South Asian MFIs. After the crisis, individual lending is favorable for ROA and operational self-sufficiency of MFIs.

\section{Conclusions and recommendations}

In this article, we examine the impact of corporate governance on the performance of the South Asian MFIs. Previous studies are conducted on the European and other continents' data (Hartarska, 2005; Mersland and Strøm, 2009). In this study, our findings are quite different from the previous studies. The whole study framework is based on insights from corporate governance literature. We investigate the performance of MFIs two-fold, financial performance on one hand and social performance on the other hand. 
JEFAS
23,46

258
Table IV.

Corporate

governance with

financial and social

performance with

control variables

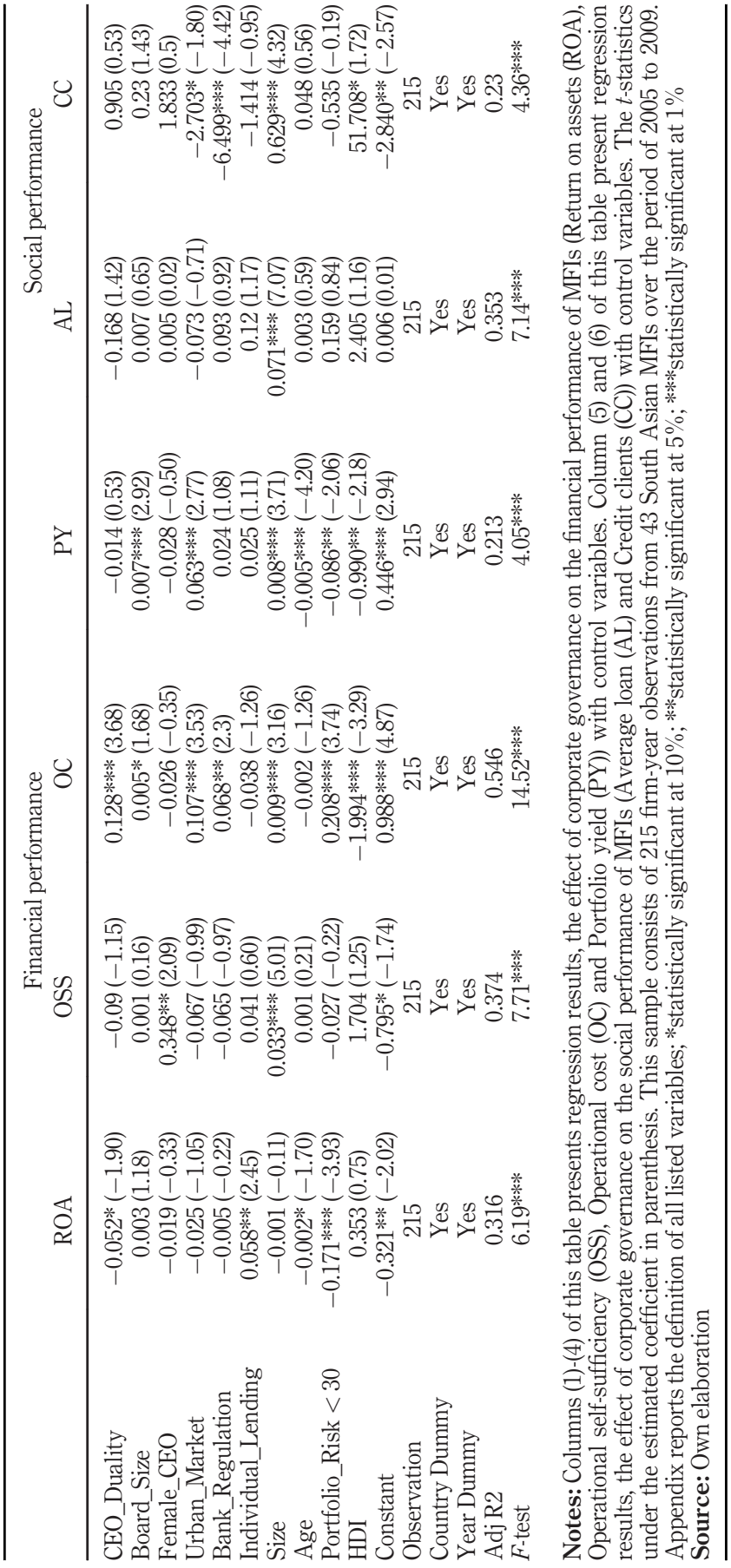




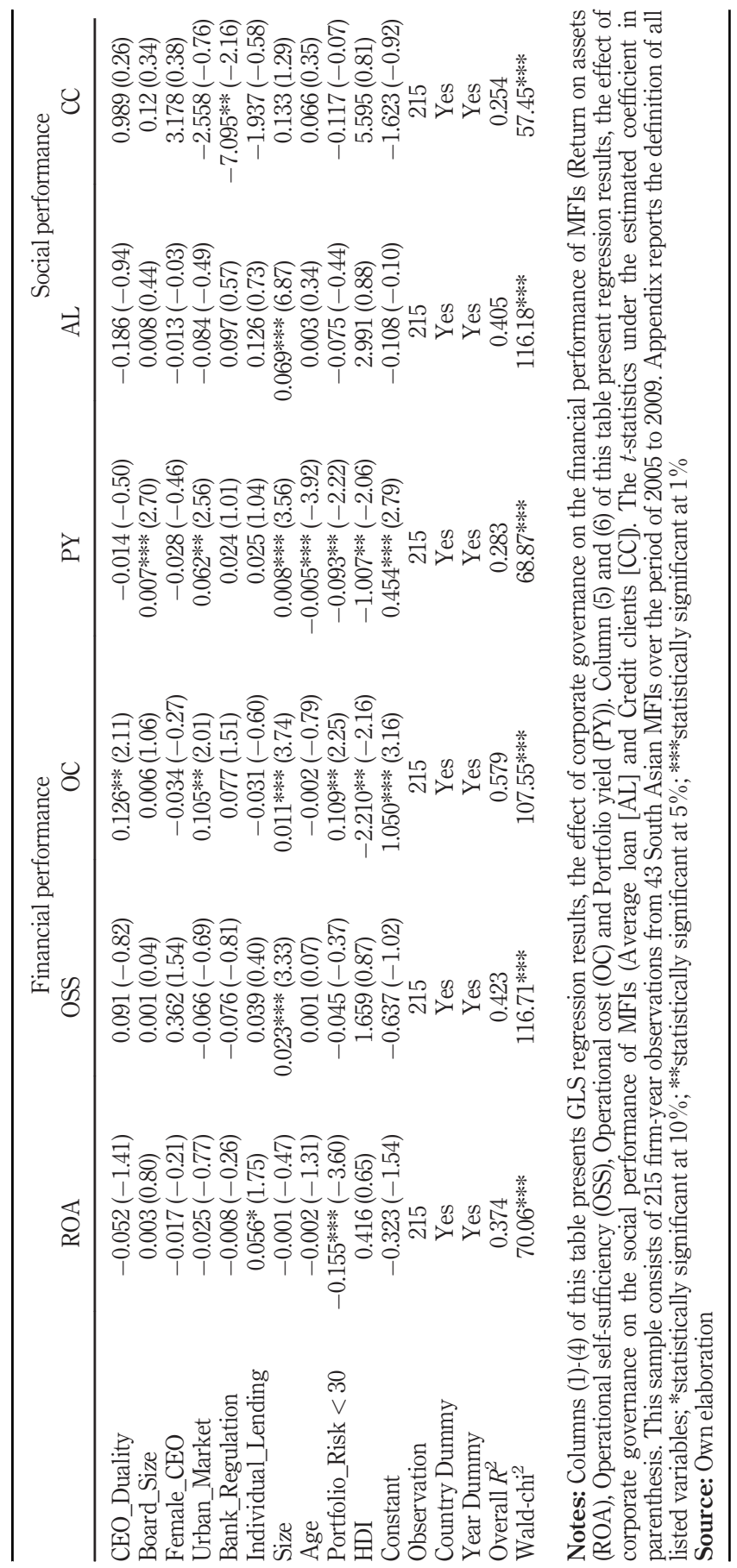

Microfinancing, governance and performance 
JEFAS

23,46

260

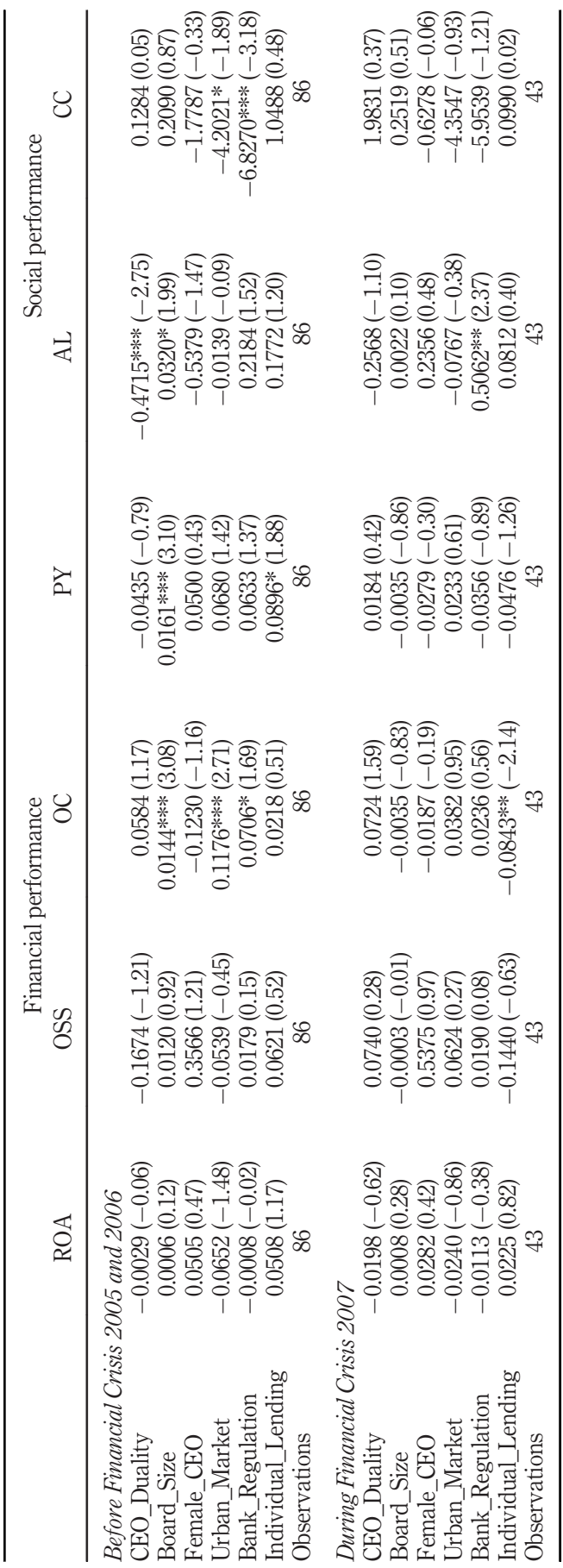

Table VI.

Corporate

governance and

performance of MFIs

before, during and

after the crisis 


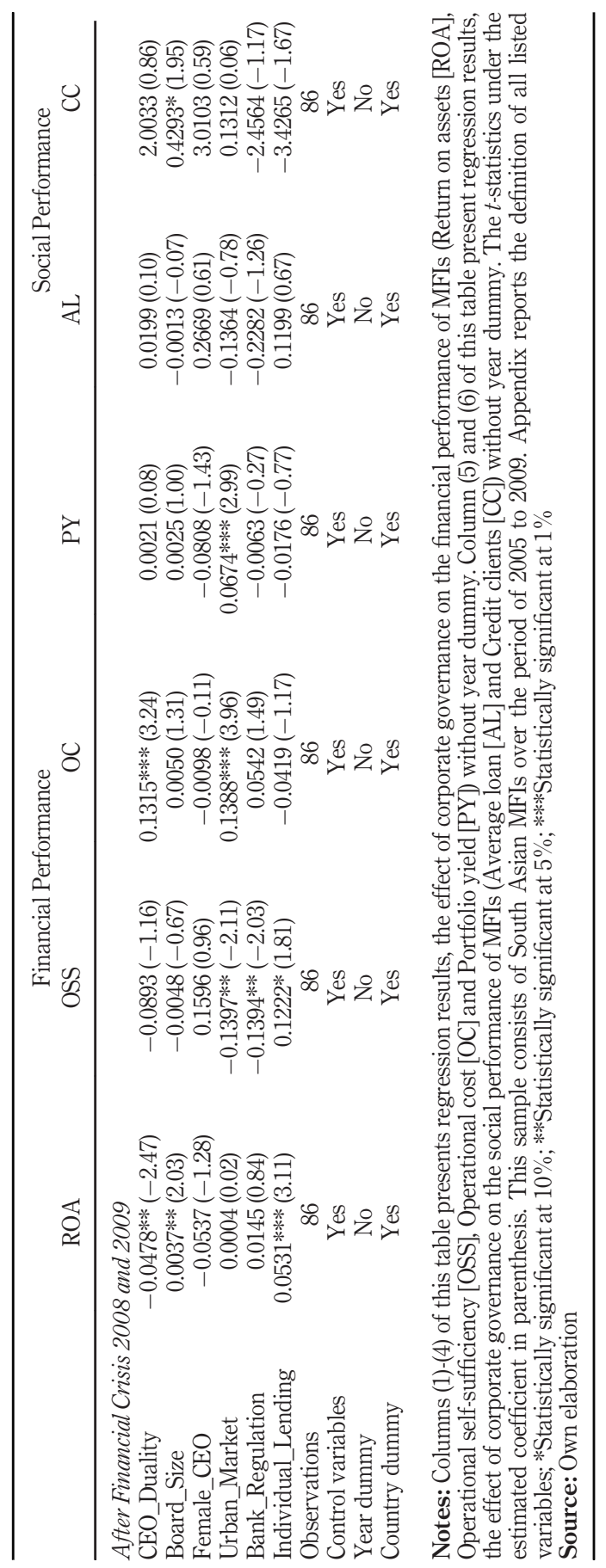

Microfinancing, governance and performance

261

Table VII.

Corporate governance and performance of MFIs before, during and after the crisis 
JEFAS 23,46

Using 43 MFIs data from six South Asian countries covering from 2005 to 2009, we find that some governance practices are not favorable for the financial health of the MFIs in South Asia. Dual leadership structure harms the financial performance of the MFIs. Large board size is very helpful for making a profitable portfolio. If the CEO chair is held by a woman, it increases the operational self-sufficiency of the MFIs. To target the maximum number of credit clients in the Asian market, the MFIs should target the rural and urban market. On the other hand, if MFIs are regulated by banks, it reduces the number of credit clients. If an institution wants to improve their profitability, it should target the individual clients instead of a group. Generally, firm size and portfolio risk greater than 30 days have a strong influence on both financial and social performance of South Asian MFIs. Before, during and after the crisis, different corporate governance attributes affect the financial and social performance of the MFIs differently. The preferable governance action for South Asian MFIs is individual lending for improving the MFIs financial performance. Taken together, we conclude that overall South Asian MFIs' governance has a significant influence on the financial and social performance.

Our analysis is based on the MFIs working in the South Asian region. The work setting of South Asia is quite different from Europe and other developed continents. India is one of the biggest counties in terms of both population and area. The total population of India is 75 per cent population of this region. So, we can say that this is the limitation of our study; the sample is not equally distributed among the countries of this region. Second limitation, Bangladesh MFI industry is at its boom. Nobel prize-winning Grameen bank is trying to provide credit to the needed people on flexible terms and conditions (Yunus, 1999). The working pattern of MFIs in Bangladesh is better than that in other countries of this region. However, we reduce these concerns by adding country level dummy.

This study contributes to the existing literature of the governance of the MFIs. The second contribution of this study is specifically provided evidence on South Asian data. Indeed, this region is totally ignored in the quality research of microfinance. Third, the importance of corporate governance for financial and social performance is separately discussed. Our motivation is to find out how MFIs can have achieved their primary (outreach) and secondary (financial) goals with the help of corporate governance actions.

\section{Notes}

1. https://openknowledge.worldbank.org/handle/10986/13722

2. https://sustainabledevelopment.un.org/post2015/transformingourworld

3. In these goals and targets, member countries resolve, between now and 2030, to end poverty and hunger everywhere.

4. The NGOs and corporates are less cost-effective and waste less resources compared to banks and nonbanking financial institutions (Servin et al., 2012).

\section{References}

Aghion, A. and Morduch, J. (2005), The Economics of Microfinance, MIT Press, Cambridge.

Ahmed, S. (2009), "Microfinance institutions in Bangladesh: achievements and challenges", Managerial Finance, Vol. 35 No. 12, pp. 999-1010, available at: https://doi.org/10.1108/03074350911000052

Armendáriz, B. and Morduch, J. (2010), The Economics of Microfinance, MIT press, Cambridge. 
Barry, T.A. and Tacneng, R. (2014), "The impact of governance and institutional quality on MFI outreach and financial performance in Sub-Saharan Africa", World Development, Vol. 58, pp. 1-20, available at: https://doi.org/10.1016/j.worlddev.2013.12.006

Bennedsen, M., Kongsted, H.C. and Nielsen, K.M. (2008), "The causal effect of board size in the performance of small and medium-sized firms", Journal of Banking and Finance, Vol. 32 No. 6, pp. 1098-1109, available at: https://doi.org/10.1016/j.jbankfin.2007.09.016

Christen, R. (2000), "Bulletin highlights", MicroBanking Bulletin, Vol. 4, pp. 41-46.

Christen, R.P., Rosenberg, R. and Jayadeva, V. (2004), "Financial institutions with a 'Double Bottom Line': implications for the future of microfinance”, CGAP Occasional Paper, Vol. 8, pp. 1-20.

Cull, R. and Morduch, J. (2007), "Financial performance and outreach: a global analysis of leading microbanks", The Economic Journal, Vol. 117 No. 517, pp. 107-133, available at: http:/dx.doi.org/ 10.1111/j.1468-0297.2007.02017.x

Eisenberg, T., Sundgren, S. and Wells, M.T. (1998), "Larger board size and decreasing firm value in small firms", Journal of Financial Economics, Vol. 48 No. 1, pp. 35-54, available at: https://doi.org/ 10.1016/S0304-405X(98)00003-8

Estapé-Dubreuil, G. and Torreguitart-Mirada, C. (2015), "Governance mechanisms, social performance disclosure and performance in microfinance: does legal status matter?", Annals of Public and Cooperative Economics, Vol. 86 No. 1, pp. 137-155. doi: 10.1111/apce.12070.

Germidis, D.A., Kessler, D. and Meghir, R. (1991), Financial Systems and Development: what Role for the Formal and Informal Financial Sectors?, Development Centre of the Organisation for Economic Co-operation and Development, Paris.

Greene, W.H. (2003), Econometric Analysis, 5th ed. Prentice Hall, New York, NY.

Hardy, D., Holden, P. and Prokopenko, V. (2003), "Microfinance institutions and public policy", Policy Reform, Vol. 6 No. 3, pp. 147-158, available at: http://dx.doi.org/10.1080/1350485032000175637

Hartarska, V. (2005), "Governance and performance of microfinance institutions in Central and Eastern Europe and the newly independent states", World Development, Vol. 33 No. 10, pp. 1627-1643, available at: https://doi.org/10.1016/j.worlddev.2005.06.001

Hartarska, V. (2009), "The impact of outside control in microfinance", Managerial Finance, Vol. 35 No. 12, pp. 975-989, available at: https://doi.org/10.1108/03074350911000034

Hartarska, V. and Mersland, R. (2012), "Which governance mechanisms promote efficiency in reaching poor clients? evidence from rated microfinance institutions", European Financial Management, Vol. 18 No. 2, pp. 218-239, doi: 10.1111/j.1468 036X.2009.00524.x.

Hartarska, V. and Nadolnyak, D. (2007), "Do regulated microfinance institutions achieve better sustainability and outreach? cross-country evidence”, Applied Economics, Vol. 39 No. 10, pp. 1207-1222, available at: http://dx.doi.org/10.1080/00036840500461840

Hossain, M. (1988), “Credit for alleviation of rural poverty: the Grameen Bank in Bangladesh", International Food Policy Research Institute, Washington, DC, Vol. 65.

Imai, K.S. and Azam, M.S. (2012), "Does microfinance reduce poverty in Bangladesh? new evidence from household panel data", Journal of Development Studies, Vol. 48 No. 5, pp. 633653, available at: http://dx.doi.org/10.1080/00220388.2012.661853

Jansson, T., Rosales, R. and Westley, G.D. (2004), Principles and Practices for Regulating and Supervising Microfinance, Inter-American Development Bank, Washington, DC.

Kennedy, P. (2008), A Guide to Econometrics, 6th ed., Blackwell Publishing, Malden, MA.

Khandker, S.R., Samad, H.A. and Khan, Z.H. (1998), "Income and employment effects of micro-credit programmes: village-level evidence from Bangladesh", The Journal of Development Studies, Vol. 35 No. 2, pp. 96-124, available at: http://dx.doi.org/10.1080/00220389808422566

Ledgerwood, J. (1998), Microfinance Handbook: an Institutional and Financial Perspective, World Bank Publications, Washington, DC. 
JEFAS 23,46
Mersland, R. and Strøm, R.Ø. (2009), "Performance and governance in microfinance institutions", Journal of Banking and Finance, Vol. 33 No. 4, pp. 662-669, available at: https://doi.org/10.1016/j. jbankfin.2008.11.009

Mix Market (2011), South Asia Profile 2011, available at: www.mixmarket.org

Mori, N., Randøy, T. and Golesorkhi, S. (2013), "Determinants of board structure in microfinance institutions: evidence from East Africa", Journal of Emerging Market Finance, Vol. 12 No. 3, pp. 323-365.

Muhammad, Y. and Jolis, A. (1999), "Banker to the poor: micro-lending and the battle against world poverty", Public Affairs.

Rahman, A. (1999), "Micro-credit initiatives for equitable and sustainable development: who pays?", World Development, Vol. 27 No. 1, pp. 67-82, available at: https://doi.org/10.1016/S0305750X(98) 00105-3

Robinson, M.S. (2001), The Microfinance Revolution: sustainable Finance for the Poor, World Bank Publications, Washington, DC.

Schreiner, M. (2002), "Aspects of outreach: a framework for discussion of the social benefits of microfinance", Journal of International Development, Vol. 14 No. 5, pp. 591-603, doi: 10.1002/ jid.908.

Servin, R., Lensink, R. and Van den Berg, M. (2012), "Ownership and technical efficiency of microfinance institutions: empirical evidence from Latin America", Journal of Banking and Finance, Vol. 36 No. 7, pp. 2136-2144, available at: https://doi.org/10.1016/j.jbankfin.2012.03.018

Strøm, R.Ø., D’Espallier, B. and Mersland, R. (2014), "Female leadership, performance, and governance in microfinance institutions", Journal of Banking and Finance, Vol. 42, pp. 60-75, available at: https://doi.org/10.1016/j.jbankfin.2014.01.014

Tchuigoua, H.T. (2015), "Determinants of the governance quality of microfinance institutions", The Quarterly Review of Economics and Finance, Vol. 58, pp. 32-43, available at: https://doi.org/ 10.1016/j.qref.2015.02.011

Tucker, J.L., III. and Kennedy-Tucker, P.E. (2004), "Equity holdings and the financial performance of managed care firms", Management Research News, Vol. 27 No. 6, pp. 1-10, available at: https:// doi.org/10.1108/01409170410784158

Wagner, C. and Winkler, A. (2013), "The vulnerability of microfinance to financial turmoil- evidence from the global financial crisis", World Development, Vol. 51, pp. 71-90.

World Bank (2006), Microfinance in South Asia, WB, Washington, DC.

Yermack, D. (1996), "Higher market valuation of companies with a small board of directors", Journal of Financial Economics, Vol. 40 No. 2, pp. 185-211, available at: https://doi.org/10.1016/0304-405X (95)00844-5

Yunus, M. (1999), “The Grameen Bank”, Scientific American, Vol. 281 No. 5, pp. 114-119. 


\begin{tabular}{|c|c|c|c|}
\hline Variable & Definition & Source & \\
\hline Dependent Return on asset & Net profit divided by total assets & MIX Market & \\
\hline Operational self-sufficiency & $\begin{array}{l}\text { Financial revenue divided by financial expense, } \\
\text { impairment loss, and Operating Expense }\end{array}$ & Same & 265 \\
\hline Operational cost & $\begin{array}{l}\text { Expenses related to operation rent, salaries, } \\
\text { advertisement etc }\end{array}$ & Same & \\
\hline Portfolio yield & The income returns on all investments & Same & \\
\hline Average loan size & $\begin{array}{l}\text { The average amount of loan given to an individual } \\
\text { person }\end{array}$ & Same & \\
\hline Number of credit clients & $\begin{array}{l}\text { A total number of credit clients targeted by MFI in a } \\
\text { single year }\end{array}$ & Same & \\
\hline Independent CEO duality & $\begin{array}{l}\text { A dummy indicating } \mathrm{CEO} \text { and chairman are the same } \\
\text { person when } 1\end{array}$ & $\begin{array}{l}\text { Author's calculation, } \\
\text { Annual Reports }\end{array}$ & \\
\hline Board size & A total number of board members & Same & \\
\hline Female CEO & A dummy indicating $\mathrm{CEO}$ is female when 1 & Same & \\
\hline Urban market & $\begin{array}{l}\text { A dummy indicating the MFI serving in the urban } \\
\text { market when } 1\end{array}$ & Same & \\
\hline Bank regulation & $\begin{array}{l}\text { A dummy indicating the MFIs of this country follow the } \\
\text { bank regulation when } 1\end{array}$ & Same & \\
\hline Individual loan & $\begin{array}{l}\text { A dummy indicating the MFIs also granted the loan to } \\
\text { the individual person }\end{array}$ & Same & \\
\hline Firm control Firm age & MFI year of experience & MIX Market & \\
\hline Firm Size & The natural log of total assets & Same & \\
\hline Portfolio risk $>30$ days & Portfolio facing risk greater than thirty days & Same & \\
\hline Country control HDI & $\begin{array}{l}\text { A composite index formed by UNDP for the lifestyle of } \\
\text { that country }\end{array}$ & UNDP Reports & $\begin{array}{l}\text { Table AI. } \\
\text { Variable definition }\end{array}$ \\
\hline
\end{tabular}

\section{Corresponding author}

Asif Saeed can be contacted at: asif.saeed@outlook.com

For instructions on how to order reprints of this article, please visit our website: 